\title{
CARBON AND OXYGEN STABLE ISOTOPES IN THE TOA BAJA WELL, PUERTO RICO: IMPLICATIONS FOR BURIAL DIAGENESIS AND HYDROCARBON GENERATION
}

\author{
Luis A. González
}

Department of Geology, The University of Iowa, lowa City

Abstract The Toa Baja Well was drilled on the coastal plains of northem Puerto Rico with a total depth of $2705 \mathrm{~m}$ [Larue, 1990]. Interstratified limestone, quartz-bearing calcareous sandstones, and shales dominate the uppermost 580 $\mathrm{m}$ and are separated from underlying rocks by an unconformity. Below this unconformity continuing to total depth, lithologies encountered consist of volcaniclastic sandstones/siltstones, pelagic carbonates, volcanic flows and either plutonic rocks or coarse-grained immature sandstones derived from plutonic bodies.

Stable isotopic data of carbonates suggest diagenetic modification under a meteoric and meteoric-marine mixing environments for sediments above $915 \mathrm{~m}$. A fracture zone near $915 \mathrm{~m}$ coincides with an abrupt shift in $\delta^{18} \mathrm{O}$ compositions indicating the presence of hotter fluids during alteration of these sediments. The depleted $\delta^{13} \mathrm{C}$ signatures occurring above a fault at $1220 \mathrm{~m}$ are suggestive of isotopically light gaseous hydrocarbons migrating through the fault and being oxidized as they dispersed through the sediment column. The abrupt shift in $\delta^{18} \mathrm{O}$ compositions and its coincidence with the fracture zone at $915 \mathrm{~m}$ suggest geopressuring and thermal buildup due to accumulation of hotter, upward migrating formational fluids. Estimated burial temperatures for the interval above $915 \mathrm{~m}$ do not exceer $140^{\circ} \mathrm{C}$ and are possibly lower due to circulating colder meteoric fluids. Maximum estimated burial temperatures for sediments below $915 \mathrm{~m}$ range from $80^{\circ}$ to a a maximum of $150^{\circ} \mathrm{C}$ at $2400 \mathrm{~m}$. The data suggests that the bulk of the sediment pile has not been exposed to temperatures above the oil window and possibly hydrocarbons have been generated deeper in the basin.

\section{Introduction}

The Toa Baja Well was drilled on the coastal plain of northem Puerto Rico, approximately $10 \mathrm{~km}$ west of San Juan, to a total depth of $2705 \mathrm{~m}$ [Larue, 1990]. The uppermost 580 $m$ consists of interstratified limestone, quartz-bearing calcareous sandstones, and shales of middle Tertiary age (Oligocene-Miocene) and are equivalent to units exposed in the heavily karstified Tertiary outcrop belt of northern Puerto Rico described by Monroe [1980] (Figure 1). The middle Tertiary strata are separated from underlying rocks by an unconformity at approximately $580 \mathrm{~m}$ of depth. Below this unconformity continuing to total depth lithologies encountered in the drillhole consist of volcaniclastic sandstones/siltstones, pelagic carbonates, volcanic flows and either plutonic rocks or coarsegrained immature sandstones derived from plutonic bodies (Figure 1). Sediments below the unconformity are interpreted as being of deep water origin and are of lower Eocene to middle Oligocene age [Larue, 1990].

In order to gain a better understanding of the diagenetic history of these sediments and appraise the possible involvement of hydrocarbons in the diagenesis of these deposits, stable carbon and oxygen isotopic studies of the carbonate sediments were undertaken.

Copyright 1991 by the American Geophysical Union.

Paper number $91 \mathrm{GL} 00396$

0094-8534/91/9LGL-00396\$03.00

\section{Methods}

Petrography is based on well cuttings sieved washed and retained on a 230 mesh screen and embedded in epoxy from which thin sections and polished chips were produced. Chips were stained with an Alizarin Red/Potassium Ferricyanide solution. Cathodoluminescence was performed using a Nuclide ELM-2 luminoscope. For materials form depths of 30 to $850 \mathrm{~m}$, microscale samples ( $=0.1 \mathrm{mg}$ powdered carbonate) were extracted from polished slabs using a microscopemounted drill assembly with drill bits of $0.50 \mathrm{~mm}$ in diameter. Due to the small cuatting size sampling of individual diagenetic components is not feasible below $915 \mathrm{~m}$. Below $610 \mathrm{~m}$ to total depth, a split from the sieved cuttings was analyzed for wholerock $\delta^{13} \mathrm{C}$ and $\delta^{18} \mathrm{O}$ composition. All stable isotope analyses were performed at the University of Michigan Stable Isotope Laboratory and are reported relative to the PDB standard.

\section{Petrography}

Diagenetic modifications of the carbonate-dominated portion above $580 \mathrm{~m}$ of the Toa Baja drillhole sequence are treated in greater detail by Gonzallez and Ruiz [1991]. Limestone fragments above the unconformity generally consist of variable amounts of benthic foraminifera, red algae, echinoderm fragments, coral and molluscan debris [Montgomery et al.,

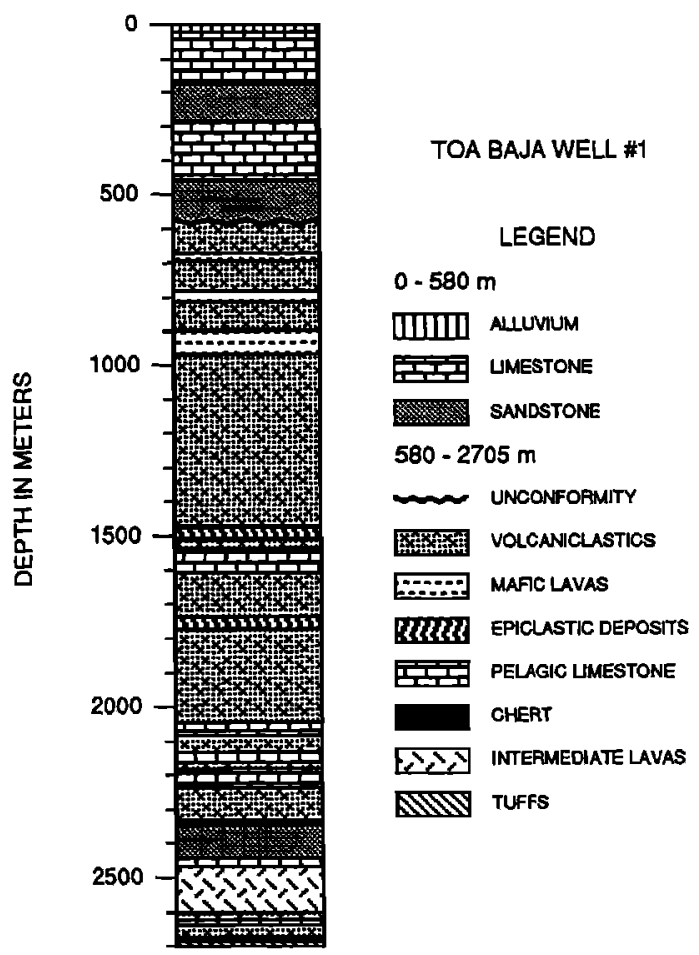

Fig. 1. Inferred lithostratigraphy of the Toa Baja Well \#1. The age range of sediments above the unconformity is middle Oligocene to Miocene in age and sediments below the unconformity are uppermost lower Eocene [after Smith et al., 1991; Montgomery et al., 1991]. 
1991]. Most of these are embedded in a micritic matrix and occasionally are rimmed by fibrous marine cements. Quartzrich calcareous sandstones and siltstones are all cemented by calcite spar or microspar. The diagenetic history of carbonate rocks encountered in the Toa Baja well can be summarized as follows: a) early marine cementation, b) skeletal aragonite dissolution and/or replacement by blocky calcite, c) fabric retentive replacement of high magnesium calcite by calcite, d) infilling of skeletal and intraskeletal porosity by equant/blocky calcite spar, e) dolomitization of selected components.

In the volcanic/volcaniclastic sequences below $580 \mathrm{~m}$, carbonates are present as pelagic deposits, vein-filling calcite spar, and microcrystalline calcite infilling secondary porosity in feldspars or calcitizing of feldspars. Pelagic carbonates show variable degrees of alteration with recrystallization increasing downhole. Vein-filling calcite in non-carbonate rocks occur as distinct fibrous fill and as a calcite mosaic (blocky spar). In fragments in which these two types of vein fill are present, blocky calcite is the late phase. Isolated blocky calcite spar fragments or those not associated with vein fills can be differentiated by their coloration into three different types: clear, cloudy (milky), and "pinkish" spar. The clear and cloudy spars are similar in appearance to those known to occur as vein fills. Down-core variability is hard to assess due to the small size of the cuttings. Because these spars coexist only in a few samples, their relative timing cannot be determined from the existing samples.

\section{Carbon and Oxygen Isotopic Compositions}

The $\delta^{18} \mathrm{O}$ composition of both whole-rock samples and component analysis can be separated into two distinct groups (Figure 2, 3). Above $915 \mathrm{~m}$ oxygen isotopic compositions range from -1.5 to $-4.2 \%$ with no systematic change with depth. Two individual analyses from calcite spars at 46 and $100 \mathrm{~m}$ deviate from this range and are interpreted by Gonzalez and Ruiz [1991] to be detrital vein calcite.

At $915 \mathrm{~m}$ there is a prominent shift in the $\delta^{18} \mathrm{O}$ compositions towards lighter values (Figure 3). $\delta^{18} \mathrm{O}$

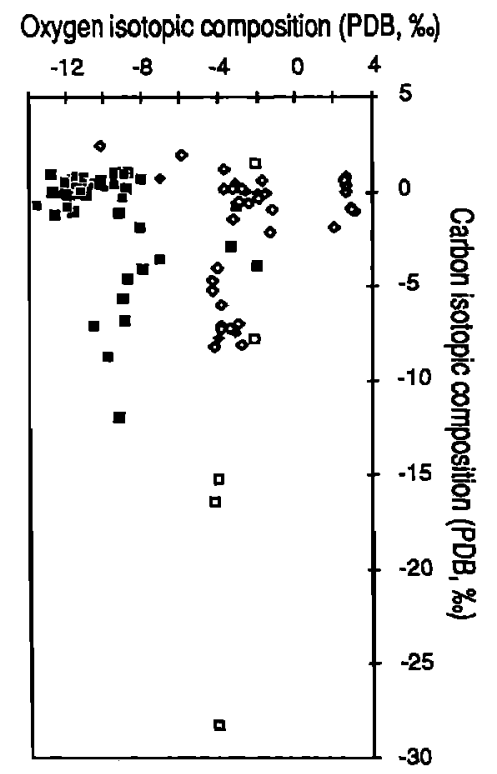

Fig. 2. Carbon-oxygen isotope cross-plot. Notice the gap in $\delta^{18} \mathrm{O}$ compositions from -4 to $-6 \%$. Solid squares $=$ whole rock, open squares = calcite spar in volcanic/igneous rock fragments, solid diamonds = calcite spars and recrystallized skeletal grains, open diamonds = carbonate grains above unconformity.
Oxygen isotopic composition (pdb, \%)

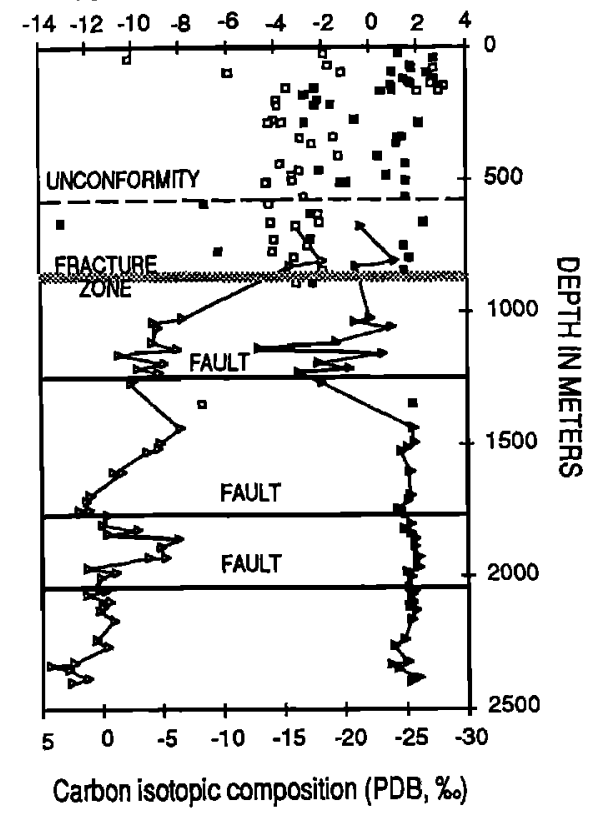

Fig. 3. $\delta^{13} \mathrm{C}$ and $\delta^{18} \mathrm{O}$ variations with depth. Squares represent are component analysis. Triangles are whole rock analysis. Solid symbols $=\delta^{13} \mathrm{C}$ and open symbols $=\delta^{18} \mathrm{O}$. Structural information from Larue [1990].

compositions range from -7.9 to $-13.7 \%$ and decrease gradually with depth. The sharp change in isotopic composition coincides with the presence of a fracture zone from 862 to $869 \mathrm{~m}$ (Figure 3). Although $\delta^{18} \mathrm{O}$ compositions generally decrease with depth, there are several spikes in this trend that coincide with fault planes described in Larue [1990].

With the exception of three data points, $\delta^{13} \mathrm{C}$ compositions of carbonates above $915 \mathrm{~m}$ range from -8.3 to $+2.4 \%$ (Figure $2,3)$. The three samples that have depleted $\delta^{13} \mathrm{C}$ values, ranging from -15.2 to $-28.2 \%$, are from clear to cloudy spars from veins in volcaniclastic fragments. Spars associated with limestone fragments do not exhibit these extremely depleted values. Pink and milky spars in volcaniclastic fragments fall within the range for all other samples.

Immediately below the fracture zone at $869 \mathrm{~m}$ and above the fault plane at $1220 \mathrm{~m}, \delta^{13} \mathrm{C}$ compositions exhibit broad variability and generally decrease with depth. Below the fault plane at $1220 \mathrm{~m}$, whole-rock samples and one pelagic mud sample have $\delta^{13} \mathrm{C}$ values that are fairly invariant. $\delta^{13} \mathrm{C}$ values range from +1 to $-1 \%$ with no systematic change with depth.

\section{Discussion}

The petrographic character of limestone fragments and their isotopic compositions suggest that the upper portion of the Tor Baja Well ( $<80 \mathrm{~m}$ ) has seen no significant burial and that diagenetic transformations occurred in early marine and in meteoric or mixed meteoric-marine environments. The isotopic data can be accounted for by a model of stabilization by fluids that were modified by progressive rock-water interactions where depleted $\delta^{13} \mathrm{C}$ and $\delta^{18} \mathrm{O}$ compositions correspond to meteoric fluids, and heavy $\delta^{13} C$ and $\delta^{18} O$ compositions correspond to fluids which have undergone extensive rockwater interactions. Carbonate diagenesis is treated in greater detail by González and Ruiz [1991].

The bulk of compositions below the unconformity at $580 \mathrm{~m}$ (1900 ft.) and down to a depth of $915 \mathrm{~m}$ could also be accounted for by meteoric diagenesis. The similarity in both $\delta^{13} \mathrm{C}$ and $\delta^{18} \mathrm{O}$ composition to those of overlying sediments 
argues at least for the same range of fluid compositions and diagenetic temperatures.

Although it could be argued that the similarity in isotopic composition of the interval between 580 to $915 \mathrm{~m}$ is due to caved carbonates from the shallower portions, analysis from spar samples in igneous and volcaniclastic fragments also have similar $\delta^{18} \mathrm{O}$ and $\delta^{13} \mathrm{C}$ compositions suggesting that fluid compositions and temperature regimes were similar. Spar samples in igneous and volcaniclastic fragments bear no resemblance to sparry carbonates in limestone fragments from the overlying shallow water carbonates and sandstones. It is possible that this portion underwent meteoric diagenesis during the exposure period that created the marked unconformity at $580 \mathrm{~m}$.

Extremely $\delta^{13} \mathrm{C}$ depleted signatures are encountered in three spar samples in igneous and volcaniclastic fragments between 580 to $915 \mathrm{~m}$. A possible $\mathrm{CO}_{2}$ source for the $\delta^{13} \mathrm{C}$-depleted carbonates is the oxidation of isotopically light hydrocarbon gases such as methane. It is difficult to evaluate from the present data whether this light gas (methane?) is sourced from bacterial reduction below the sulfate reduction zone during early diagenesis [Gautier and Claypool, 1984; Curtis and Coleman , 1986], or produced during catagenesis deeper in the basin with migration through the fracture/fault system. The lack of other indicators associated with early diagenesis in the sulfate reduction and bacterial reduction zones such as siderite, iron sulfides, and ferroan carbonates and dolomite [Gautier and Claypool, 1984; Curtis and Coleman , 1986], would suggest that methane or the $\delta^{13} \mathrm{C}$-depleted $\mathrm{CO}_{2}$ was not a product of early diagenesis in sulfate reducing environments.

As the $\delta^{18} \mathrm{O}$ compositions of the three spar samples between 580 to $915 \mathrm{~m}$ are similar to that of other spars and carbonates, we can rule out fluid migration through the fracture/fault system from a different reservoir sourced deeper in the basin. Furthermore, if the $\delta^{18} \mathrm{O}$ signatures are indeed derived from meteoric fluid as suggested above it implies that isotopically light $\mathrm{CO}_{2}$ was introduced when the sequence was exposed and a deep meteoric lens was present.

The marked difference in oxygen isotopic compositions of the sedimentary rocks below the fracture zone at $869 \mathrm{~m}$ suggests that the rocks in the two portions of the well have been altered by fluids of different isotopic compositions, and/or different temperatures. The high variability of carbon isotopic compositions for samples between the fracture zone and the fault at $1220 \mathrm{~m}$ also indicates an influx of isotopically light $\mathrm{CO}_{2}$. The coincidence of the fault at $1220 \mathrm{~m}$ and the depleted $\delta^{13} \mathrm{C}$ compositions suggests a relationship between these two. It is possible that the fault acted as a conduit for isotopically light gaseous hydrocarbons that were oxidized to $\mathrm{CO}_{2}$. The absence of solid hydrocarbons in the section argue for migration only of gaseous hydrocarbons. It is possible that the $\delta^{13} \mathrm{C}$ depleted gas for the sediments between the fracture zone and the fault at $1220 \mathrm{~m}$ and for the spars between the unconformity and the fracture zone had the same source. The variability in whole-rock $\delta^{13} \mathrm{C}$ compositions for the 915 to $1220 \mathrm{~m}$ interval can be attributed to variable contribution by carbonates having $\delta^{13} \mathrm{C}$ compositions ranging from -1 to +1 $\%$ (range of values of underlying carbonates) and diagenetic calcite with compositions ranging from -30 to $-15 \%$.

An alternative source for isotopically light $\mathrm{CO}_{2}$ is volcanogenic $\mathrm{CO}_{2}$ having composition ranging from -14 to -28 \%o PDB [Faure, 1986]. Given the inferred deep water setting for the sediments below $580 \mathrm{~m}(1900 \mathrm{ft}$.) [Smith et al., 1991; Montgomery et al., 1991] it likely that the lava flows present had undergone substantial cooling and degassing prior to significant accumulation of sediments took place. If this is the case isotopically light $\mathrm{CO}_{2}$ contributed from volcanic sources would be insufficient to induce marked changes in bulk rock isotopic compositions. In addition if volcanogenic $\mathrm{CO}_{2}$ from the lavas was the source we would expect the depleted carbon isotopic values to be concentrated immediately above and/or below the lava flows. Lastly it must be noted that methane has been detected in the well and its abundance seems to be maximized near fault planes [Larue, 1990] suggesting that the faults are presently acting as conduits for methane generated deeper in the basin.

If indeed there is a single source for the $8^{13} \mathrm{C}$ depleted $\mathrm{CO}_{2}$ for sediments below and above the fracture zone, it could be argued that the fault at $1220 \mathrm{~m}$ served as the only conduit for these gases. The differences in $\delta^{18} \mathrm{O}$ compositions would indicate two different fluids and/or temperatures above and below the fracture zone. It is likely that colder meteoric fluids are (were) circulating above the fracture zone, and that marinederived brine were circulating below it. The present-day uniform geothermal gradient and downhole temperatures argue against present-day circulation of hotter fluids.

A difference of 2 to $3 \% 0$ in the $\delta^{18} \mathrm{O}$ of fluids below the fracture zone could account for the observed shift in $\delta^{18} \mathrm{O}$ composition without the need of a temperature shift. As the present-day meteoric-marine transition occurs between 200 and $300 \mathrm{~m}$. below the surface [Gomez-Gomez, 1987], it is difficult to argue for fluids other than marine or marine derived brine to be present at the depth of the $\delta^{18} \mathrm{O}$ shift. With marine fluids present under the fracture zone a temperature must have been at least $20^{\circ} \mathrm{C}$ higher below the fracture zone. It is likely that fluids derived from compaction and reacting with the sediments would get progressively enriched in $\delta^{18} \mathrm{O}$ [Longstaffe, 1989]. If brines derived in this manner were as heavy as $4 \%$ a temperature shift of approximately $40^{\circ} \mathrm{C}$ would be required to produce the observed $\delta^{18} \mathrm{O}$ values.

A scenario that would account for an abrupt temperature induced shift towards lighter $\delta^{18} \mathrm{O}$ and for the fracture zone is geopressuring. If the volcanic flow at $915 \mathrm{~m}$. (3000 ft.) acted as a hydraulic barrier (seal), as sediments were compacting and dewatering, anomalous pressures and thermal buildup would be induced [Jones, 1980]. Geopressuring or aquathermal pressuring would be enhanced if thermobaric fluids were migrating upwards through the faults [Jones, 1980; Galloway, 1984]. With increasing pressure buildup due to compaction, dewatering and perhaps migration of thermobaric fluids through the fault the confining layer would fracture restablishing normal flow and allowing thermal equilibrium, such as in present conditions.

Below $1220 \mathrm{~m}$ a significant contribution by isotopically light $\mathrm{CO}_{2}$ cannot be detected, and it is likely that the carbonate system was dominated by dissolution-reprecipitation of marine-derived carbonates, and hence the heavier invariant $\delta^{13} \mathrm{C}$ compositional range. Although the $\delta^{18} O$ compositions exhibit a gradual decrease with depth, this trend is offset at the recognized fault planes (Figure 3).

Two possible scenarios can explain the correlation of $\delta^{18} \mathrm{O}$ spikes with faults. The first alternative is that the faults acted as conduits for fluids migrating from deeper to shallower portions of the basin. Hotter fluids migrating upwards through the faults and dispersing through the sediment column would account for the lighter compositions immediately above fault planes. The second possibility is that faulting has offset the sediment package, causing stacking of sediment packages with overlapping degrees of burial-induced recrystallization. For example, it is possible that the sediment packet bounded by faults at 1220 and $1770 \mathrm{~m}$ experienced the same temperatures throughout the interval as the sediment packet bounded by the faults at 1770 and $2040 \mathrm{~m}$, as both have a similar ranges of $\delta^{18} \mathrm{O}$ compositions. It is difficult to resolve between these two alternative scenarios for the offset in $\delta^{18} \mathrm{O}$ compositions. It is probable that a combination of these two scenarios, fluid migration and offsets by faulting, is responsible for the observed downhole variability in $\delta^{18} \mathrm{O}$.

Based on the observed range of $\delta^{18} 0$ compositions an estimate can be made of the range of diagenetic temperatures for these sediments (Figure 4). For sediments above the fracture zone, a meteoric fluid with composition similar to 


\section{Oxygen Isotopic composition (PDB, \%)}

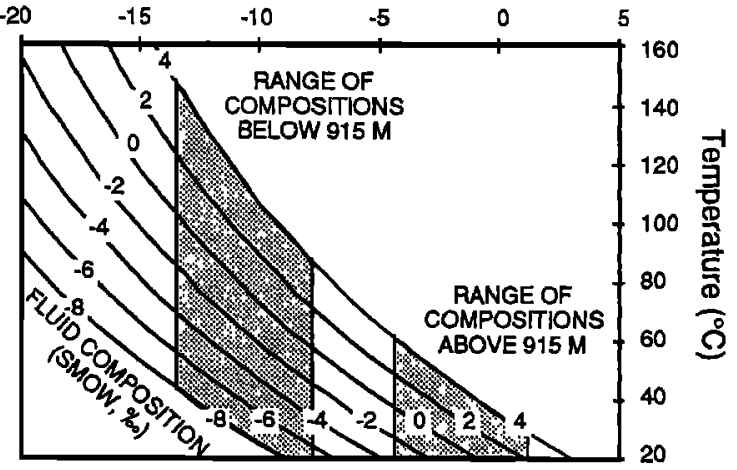

Fig. 4. Estimated calcite formation temperatures. ${ }^{18} \mathrm{O} \alpha$ for calcite-water system were calculated using $10^{3} \ln \alpha=2.78$ $\left(10^{6} / \mathrm{T}^{2}\right)-2.89$ [ Friedman and O'Neil, 1977].

those of the present-day can be assumed. The $\delta^{18} \mathrm{O}$ composition of modern meteoric fluids can be estimated to be approximately $-2 \%$, based on cave carbonates and measured cave temperatures from northern Puerto Rico [González, 1989]. Thus, if meteoric to marine fluids were responsible for alteration, temperatures ranging from 23 to $40^{\circ} \mathrm{C}$ are estimated. For sediments below the fault at $1220 \mathrm{~m}$ a range of temperatures can be estimated to be from 40 to $60^{\circ} \mathrm{C}$ hotter at $2440 \mathrm{~m}$ than at $1220 \mathrm{~m}$ depending on fluid $\delta^{18} \mathrm{O}$ compositions. If a fluid $\delta^{18} \mathrm{O}_{\text {SMOW }}$ composition of $0.0 \%$ is assumed, temperature estimates range from 60 to $105^{\circ} \mathrm{C}$, while for heavier fluids with $\delta^{18} \mathrm{O}_{\text {SMOW }}=4.0 \%$, temperatures would range from 85 to $145^{\circ} \mathrm{C}$. Regardless of the fluid compositions assumed to estimate burial diagenetic temperatures, isotopic data suggests that the bulk of the carbonate sediments in the Toa Baja Well have experienced no diagenetic transformations at temperatures in excess $150^{\circ} \mathrm{C}$.

Although Cho [1991] estimates paleotemperatures of 160 to $195^{\circ} \mathrm{C}$ at a depth of $2350 \mathrm{~m}$ the estimates are not incompatible with carbonate estimates. Since the carbonate $\delta^{18} \mathrm{O}$ compositions have been derived from whole rock (cuttings) analysis it is possible that higher temperatures are recorded by carbonate spars and their signature is overwhelmed by that of marine derived carbonate. Alternatively it is possible that carbonate alteration took place under lower geothermal regimes prior to, or after low grade metamorphism.

\section{References}

Cho, M., Zeolite to prehnite-pumpellyite facies metamorphism in the Toa Baja Drill Hole, Puerto Rico, GRI, this volume, 1991.
Curtis, C.D., and Coleman, M. L., Controls on the precipitation of early diagenetic calcite, dolomite and siderite concretions in complex depositional sequences, in Roles of organic matter in sediment diagenesis, edited by D. L. Gautier, SEPM Spec. Pub. 38, p. 23-33, 1986.

Faure, G., Principles of Isotope Geology, 589 p, John Wiley, New York, 1986.

Friedman, I., and O'Neil, J.R., Compilation of stable isotope fractionation factors of geochemical interest, in Data of geochemistry (6 ${ }^{\text {th }}$ edition), edited by M. Fleischer, U.S. Geol. Surv. Prof. Paper 440-KK, 110p, 1977.

Galloway, W.E., Hydrogeologic regimes of sandstone diagenesis, in Clastic Diagenesis, edited by D.A. McDonald, and R.C. Surdam, AAPG Mem. 37, p. 3-13, 1984.

Gautier, D.L., and Claypool, G.E., Interpretation of methanic diagenesis in ancient sediments by analogy with processes in modern diagenetic environments, in Clastic Diagenesis, edited by D.A. McDonald, and R.C. Surdam, AAPG Mem. 37, p. 111-123, 1984.

Gomez-Gomez, F., Planning report for the Caribbean islands regional aquifer-system analysis project, U.S. Geol.Surv. Water-Res. Rep. 86-4074, 50p, 1987.

González, L.A., and Ruiz, H.M., Diagenesis of Middle Tertiary Carbonates in the Toa Baja Well, Puerto Rico, GRL, this volume, 1991.

Jones, P.H., Role of geopressure in the hydrocarbon and water system, in Problems in petroleum migration, edited by W.H. Roberts III, and R.J., Cordell, AAPG Stud. Geol. 10, p. 207-216, 1980.

Larue, D.K.Toa Baja Drilling Project, Puerto Rico, Eos Trans. AGU, v. 71 , p. 233-234, 1990.

Longstaffe, F. J.,,Stable isotopes as tracers in clastic diagenesis, in Short colirse in burial diagenesis, edited by $\mathrm{I}$. E. Hutcheon, Mineral. Soc. Can., p. 201-277, 1989.

Montgomery, H., Robinson, E., Saunders, J., and Van den Bold, V., Paleontology of the Toa Baja Well, Puerto Rico, GRL, this volume, 1991.

Monroe, W.H., Geology of the Middle Tertiary Formation of Puerto Rico, U.S. Geol. Surv. Prof. Pap. 953, 93p, 1980.

Smith, A.L., Severin, K, and Larue, D.K., Stratigraphy, geochemistry and mineralogy of Eocene rocks from the Toa Baja Drillhole, GRL, this volume, 1991.

Luis A. González, Department of Geology, The University of Iowa, Iowa City, Iowa 52242

(Received September 21, 1990;

revised December 20, 1990;

accepted December 21, 1990.) 